\title{
Some Thoughts on the Interim Preservation of the Namibian Fishing Heritage
}

\author{
By D.J. Devine
}

\section{The Legal Background}

In 1920 the League of Nations granted South Africa a Mandate to administer the territory of South West Africa. The League was wound-up after the Second World War. The newly-created United Nations tried to get South Africa to convert the territory into a United Nations Trust Territory so that it could supervise the administration of the territory. South Africa refused to do so and friction over this issue built up between it and the world organisation. It was alleged that South African administration was not observing the terms of the Mandate. Eventually in 1966 the General Assembly of the United Nations purported to revoke the Mandate. ${ }^{1}$ The Security Council confirmed this ${ }^{2}$ as did the International Court of Justice in an Advisory Opinion. ${ }^{3}$ To administer the territory the United Nations created the United Nations Council for Namibia. ${ }^{4}$ In 1973 a United Nations Commissioner for Namibia was appointed and the General Assembly recognized SWAPO as the "authentic representative of the Namibian people". ${ }^{5}$ South Africa contests the validity of the various measures taken by the United Nations and the status of the Council for Namibia. ${ }^{6}$ A settlement proposal was accepted by South Africa and SWAPO in 1978 and this was endorsed by the Security Council. ${ }^{7}$ A settlement has however failed to materialize and so the states of the territory appears to be somewhere in a legal limbo between South Africa and the United Nations.

1 General Assembly Resolution 2145 (XXI) of 23/9/1966.

2 Security Council Resolution 276 (1970).

3 Advisory Opinion on Legal Consequences for States of the Continued Presence of South Africa in Namibia/ South West Africa, 1970 I.C.J. Rep. 16.

4 General Assembly Resolution 2248 (XXII).

5 Resolution 3111 (XXVIII).

6 The basic arguments could be resumed under the following headings: (i) there have been no breaches of the Mandate or none have been proved; (ii) even if there were breaches of the Mandate that would not be a ground for terminating it; (iii) even if there were grounds for terminating the Mandate, the United Nations could not do it as it is not the legal successor of the League of Nations; (iv) even if the United Nations could terminate the Mandate, its General Assembly organ could not because this organ cannot make binding decisions in matters of substance. The Security Council decision of 1970 is also criticized on various grounds which place a question mark over its legal effectiveness. The advisory opinion of the International court is not binding. The overall result is that not one of the actions taken can be deemed to settle the legal situation in a conslusive manner. For aninstance typif ying the South Af rican attitude to claimed United Nations competences see the Declaration which it made on signing the Law of the Sea Convention, 1982.

7 Security Council Resolution 435 (1978). 
It is not the purpose of this paper to examine the precise status of the territory but simply to draw attention to the fact that (i) a settlement has not been achieved, (ii) this has produced a situation in which neither South Africa nor the United Nations Council can take practical steps of a legal nature to protect the interests of the territory and in particular the living marine resources. The inability is, therefore, a source of prejudice to the interests involved. The prejudice may very well continue until a final solution has been achieved and this is generally recognized.

\section{The Factual Situation}

The waters of Namibia contain such rich resources of fish that they have been frequented by long-distance fishing ships for a considerable length of time. Outside the 12 mile zone from the coastline ${ }^{8}$ there are few restrictions on exploitation of living resources. ${ }^{9}$ The result is that the zone is being plundered of its resources principally by fishing fleets from the USSR, Bulgaria, Cuba, East Germany, Poland and Rumania. In March, 1983, of 185 ships operating in waters off Namibia, 121 belonged to Eastern Block countries. The ships fish with non-regulation small-mesh nets and are not controlled by South African patrols. Annual losses in fish stocks have been estimated at about $71 / 2$ million dollars. ${ }^{10}$ The situation continues and may continue until a final solution is achieved which is accorded general recognition. ${ }^{11}$ It is clear, of course, that if there should be an independent Namibia generally recognized by other states, it could create a 200 mile exclusive fishing zone (or Exclusive Economic Zone). ${ }^{12}$ This in turn would be generally recognized also and would therefore be respected by the international community. Long-distance fishing fleets would not be able to plunder the resources in question with impunity on the pretext

8 Territorial Waters Act No. 87 of 1963, Section 3.

9 It should be noted however that ICSEAF (International Commission for South East Atlantic Fisheries) have established a variety of measures off the South West African/Namibian coast. These relate inter alia to the size of trawl net meshes, particularly for hake and horse mackerel fishing; closed pilchard seasons and trawl fishing in general. See Recommendations 2.1. of $18 / 12 / 1973 ; 2.2$. of $18 / 12 / 1980 ; 2.5$. of 17/12/1977); 2.6. of 15/12/1979 (as amended) reproduced in ICSEAF Handbook of Regulatory Measures. 1984, pp. 13-16. In ICSEAF, initiatives were taken by South Africa which led to the framing of practically each conservation measure adopted for waters off South West Africa/Namibia. See G. H. Stander, "Aspects of Marine Conservation in South Africa: Progress and Problems", Proceedings of Symposium Convened by the Hydrographic Society of South Africa, University of Cape Town, 1985, p. 11.

10 See (88) Revue Générale du Droit International Public, 1984, pp. 730-1. In 1983 the USSR, Eastern Europe and Cuba accounted for $50 \%$ of the hake catch (compared with Spain $26 \%$ and South Africa $7 \%$ ). The USSR, Eastern Europe and Cuba accounted for $84 \%$ of horse mackerel) compared with South Africa 6 1/2 \%). See Richard Moorson, Explociting the Sea, 1984, (No. 5 of Series on a Future for Namibia) p. 60. In 1984 the pattern continued. The USSR, Eastern Europe and Cuba accounted for $51 \%$ of the hake catch (compared with Spain $32 \%$ and South Africa $8 \%$ ). The USSR, Eastern Europe and Cuba accounted for $80 \%$ of horse mackerel (compared with South Africa's $15 \%$ ). See (1986) 41 South African Shipping News and Fishery Industry News, No. 1. p. 21.

11 Moorsom, ibid., pp. 70-71 says that this may be due to the tendency of ICSEAF delegates to go for maximum quotas and other reasons.

12 Ibid., p. 71 . 
that there was no valid 200 mile exclusive zone since nobody had the legal right to create one. A final solution of the Namibian question does not however appear to be in the immediate offing so the question is what practical measures could now be taken to prevent the depletion of resources pending a final solution. These measures, if they are to work would have to have two characteristics (i) They should be provisional or interim. A solution to the preservation of living resources needs to be introduced even if the status of the territory itself has not yet been definitely settled; (ii) They should be without prejudice. They should, therefore, take into account the positions of the United Nations Council, South Africa and of a future Namibian Government. None of these parties should be deemed to have abandoned its stance on the legal issues involved simply because it participates in an interim solution, perhaps even co-operating with other protagonists. Neither should any of the parties be deemed to admit the stance of any other party on the legal issues by virtue of its participation. Claims and rights, such as they may exist, should not be strengthened or weakened by the fact of participation. Participation should in fact be irrelevant to the existing legal status quo whatever that may be. ${ }^{13}$

\section{Existing Solutions and Their Limitations}

Two main regimes appear to be developing side by side and they would even appear to be alike. They are the South African solution and that of the United Nations Council. Each regime is overlapped by an international regime of a limited character within the framework of ICSEAF.

\section{The South African Solution}

Up to 1977 the maritime zones of Namibia/South West Africa were the same as those of South Africa itself. They were in fact created by the same Act of Parliament. ${ }^{14}$ The zone created was a 12 mile fishing zone from low-water mark. ${ }^{15}$ As a result of depletion of resources South Africa created a 200 mile fishing zone for itself in $1977^{16}$ and this had a very great effect in reducing foreign fishing off its coast. The result was that by the early 1980s fish stocks were again being replenished. ${ }^{17}$ The 1977 legislation did not however apply to South West Africa. ${ }^{18}$ The reason for this might be the desire to avoid conflict in

13 An example of a disputed legal status wherein rights such as they may be are frozen will be found in the Antarctica Treaty 1959, Article IV. States who have territorial claims in Antarctica and those who dispute those claims may both participate in the operation of the Treaty, the former without weakening any rights it may have, the latter without conceding any such rights.

14 Territorial Waters Act No. 87 of 1963.

15 Ibid., Section 2.

16 Territorial Waters (Amendment) Act No. 98 of 1977, Section 3.

17 Stander, note 9 supra, pp.6-7.

18 Territorial Waters (Amendment) Act No. 98 of 1977, section deleted the definiton of the Republic which under Act No. 87 of 1963 included South West Africa. 
view of the disputed status of the territory at the time (and since) coupled perhaps with the burden which patrolling such an extensive Namibian zone would impose. In the same year 1977, the Walvis Bay enclave, which up to then had been administratively part of South West Africa was re-incorporated into the Cape Province for alle purposes. ${ }^{19}$ The result is that the Walvis Bay enclave has a 200 mile fishing zone. ${ }^{20}$ A new Marine Affairs Bill of 1985 will create a South African Exclusive Economic Zone (EEZ) if it becomes law. ${ }^{21}$ It is interesting to note here that this EEZ will also exist off 13 small uninhabited islands which all stand within a short distance of the Namibian coast and over which South Africa exercises territorial sovereignty. ${ }^{22}$ The presence of these islands will undoubtedly give rise to delimitation problems both landward and seaward of the islands ${ }^{23}$ but it is not the intention of this paper to investigate such problems. This paper will confine itself to the general question of preserving living resources in waters within 200 miles of the Namibian coastline, the status of which is not complicated either by the existence of the Walvis Bay enclave or the South African islands - in other words those waters which would undoubtedly be Namibian if Namibia were to be independent.

In 1979 the Administrator-General of South West Africa made regulations in terms of which the legislation on maritime zones for the territory was to be brought into line with the South African legislation. ${ }^{24}$ A 200 mile fishing zone was created. The structure therefore exists for the protection of the living resources of the zone in question and it is now necessary to dwell upon its defects and limitations in this respect. The following observations may be made.

19 Proc.R.202 GG.5731 of 31/8/1977 (Reg.Gaz.2525). The Council for Namibia and SWAPO have condemned this move and the Security Council have called for the return of the enclave to an independent Namibia. See Moorsom, note 10 supra, pp. 74-75. South African legal title to Walvis Bay would appear however to rest on a firm basis. See J. Dugard, Annual Survey of South African Law. 1977, p. 54; the writer, "Southern Af rica and the Law of the Sea: Problems Common, Uncommon and Unique", forthcoming in $A C T A J U R I D I C A$. Future Namibian claims to Walvis Bay must therefore be of a political character rather than of a legal one.

20 The writer arrived at this conclusion af ter discussing the interpretation to be given to the relevant legislative provisions (see notes 16, 19 supra) in "Some Observations on South African Maritime Zone Legislation", (1985) 1 Sea Changes, p. 107 at pp. 109-113.

21 GN.712 GG.9996 of $1 / 11 / 1985$.

22 These are listed in Schedule 1 to the Bill. The islands are Little Roastbeef, Sinclair, Plumpudding, Pomona, Albatross, Possession, Long Islands. Halifax, Penguin (Pikkewyn), Seal, Ichaboe, Mercury and Hollamsbird. On the question of legal title to these islands see comments in note 19 supra.

23 See the writer note 19 supra. For a map showing a possible South African EEZ of Walvis Bay and the islands (note 23 supra) see Moorsom, note 10 supra p. 76. The latter suggests that Namibia should put pressure on South Africa in the future by claiming management of the entire area through ICSEAF. If South Africa resisted it would risk international confrontation. If it did not it would prejudice its claims. See p. 79. The writer considers that it would be more appropriate to settle such problems either in a delimitation agreement or by arbitration rather than by initiating what is, in effect, a policy of brinkmanship in which the "Hobson's choice" of fered might not turn out as expected.

24 Proclamation AG.4034 Official Gazette Extraordinary of South West Africa 7/11/1979; Proclamation AG.4424 ibid., 30/3/1981. 


\section{(a) Legal Uncertainty in Municipal Law}

Though the Administrator-General has purported to give effect to the operation of the 1979 regulations, ${ }^{25}$ it is not altogether clear whether or not they are in operation since ultimately they depend on the assent of the State President of the Republic to bring them into operation. ${ }^{26}$ If this is so it would be very difficult to enforce fishing conservation measures even against ships flying the South African flag in the waters in question unless this was done on the basis of flag-state jurisdiction. Enforcement against foreign ships would be out of the question.

\section{(b) International Law Uncertainties}

Since South Africa's right to create a 200 mile EEZ off Namibia must ultimately depend on whether the Mandate has been validly revoked or not, ${ }^{27}$ a matter which as we pointed out, has not been finally and conclusively determined in a legally binding manner, it follows that there would be great uncertainty about the international law validity of such a zone even if it should be clearly seen to exist in municipal law. The result would be that the right to enforce conservation measures in the zone against foreign ships would not be admitted by the flag states and would be fraught with danger. ${ }^{28}$

There could even be difficulty in the 12 mile fishing zone established in $1963 .{ }^{29}$ Though the zone certainly exists legally and is opposable to all third states since it was created before 1966, the South African right to administer the zone and enforce measures in it could be a matter of dispute in the post 1966 era. ${ }^{30}$ It does not necessarily follow from the fact that the zonal status is opposable to third states that the right to enforce in the zone is similarly opposable. ${ }^{31}$

\section{(c) Practical Difficulties}

It could be that even if the above difficulties could be solved, the enforcement of conservation measures in the 200 mile zone might simply impose such a burden on the slender South African patrolling resources that the country might be unwilling to shoulder the additional tasks and expenses involved. ${ }^{31 a}$

25 Ibid. (Proclamation AG.4424).

26 See the writers discussion of this question in his article, note 20 supra. p. 120, footnote (9).

27 Note (1) supra.

28 The UN Council for Namibia made a Declaration in 1980 condemning South Africa's extensions as illegal. See Moorsom, note (10) supra, p. 71.

29 Note (15) supra.

30 Note (1) supra.

31 See for example the allegation of Moorsom, note (10) supra, p. 73 that ICSEAF "verges on illegality" by accepting South Africa's control of fishing within territorial waters as giving it a right to manage Namibian fish resources.

31a In the past it has not been possible to have extensive patrols even to control locally based fishing. See D. 


\section{The United Nations Solution}

The United Council promulgated a 200 mile EEZ off Namibia in $1985 .{ }^{32}$ It has therefore also created a legal structure for the preservation of living resources in the zone and it is thus necessary to dwell on the defects and limitations inherent in this structure.

\section{(a) "Municipal" Law Amplification}

For practical purposes we can equate the United Nations Council regulation creating the zone as being equivalent to, or of the same nature as, the legislation of a state doing likewise. ${ }^{33}$ On the assumption that such legislation is valid it would still need to be amplified by further "municipal" legislation in order to achieve the necessary objectives. Thus the Council would need to create further legislation on detailed matters concerning fishing and conservation. This would be similar in nature to the legislation of a state doing the same thing. The simple amplification or enactment of "municipal" law in this sense would not pose insuperable problems. ${ }^{34}$

\section{(b) International Law Uncertainties}

There are several problems which present themselves here. They arise from the following three factors (a) the South African legal stance, (b) the attitude of the Soviet Union (USSR) and (c) the attitude of SWAPO.

\section{The South African Stance}

We have seen that South Africa denies the competence of the United Nations Council for Namibia and that whether South Africa or the Council is correct in this respect has never been determined in a conclusive and legally binding process. Despite the views of the overwhelming majority of states on the legal situation ${ }^{35}$ the matter is not res judicata.

Cram, "Hidden Elements in the Development and Implementation of Marine Resource Conservation Policy", Wiley series in Advances in Environmental Science and Technology. Vol. 11, 1981 (ed.R.L.Metcalf) p. 137 at p. 143.

32 A declaration as to its intention to do this was made as early as 1980 . See note (28) supra. Cape Times, 5th December, 1985.

33 If valid, it is also probably international law and in particular international constitutional law as the internal law of an international organization. On the latter see G. Schwarzenberger \& E. D. Brown, A Manual of International Law, 6th ed., 1976, pp. 218-221.

34 It has been suggested that these objectives could be achieved if the UN Council joined ICSEAF. The latter could not then ignore its views when establishing provisions. Nearly all nations which trawl off Namibia would be involved and they would be obliged to respect the provisions. See Moorsom, note (10) supra, pp. 72-73.

35 The authority of the UN Council is recognized by most members of the International Community. Ibid., p. 71 . 
Hence the right of the Council to create the zone in question, to legislate for it and to take enforcement measures in it could be contested by South Africa. ${ }^{36}$ Given the near proximity of South Africa to the area in question, its factual presence in the territory and its legal standpoint, it would be extremely difficult to enforce Council measures in the area unless other states voluntarily respected them and there would always be the spectre of doubt as to their inherent validity. ${ }^{37}$

\section{The USSR Attitude}

We have seen that the USSR is one of the main, if not the principal actor, involved in the exploitation of the living resources of waters off Namibia. ${ }^{38}$ It is not surprising therefore that it objected to the creation of an EEZ by the Council. ${ }^{39}$ This standpoint could be correct if the Mandate has not been validly terminated. It would also be correct if the creation of the EEZ exceeded the internal constitutional capacity of the Council. Though there is a presumption that the international organization has not exceeded its powers it is a rebuttable one. ${ }^{40}$ It would morever appear o be most unlikely that either of the above issues will be determined in a legally binding and conclusive manner. ${ }^{41}$ The result of this is that the Council's EEZ and any provisions it may adopt on it may not be opposable to the USSR. ${ }^{42}$ Thus enforcement against the USSR, even assuming that it should be physically possible, is legally problematic.

36 Whatever rights South Africa may have in the matter it has been careful to keep by the device of protest. See note (6) supra. It is unlikely that other states could in general contest Council authority because of the recognition factor mentioned in the previous footnote which would make Council authority opposable to them. Thus, at the very least, Council authority would have a very substantial degree of relative validity.

37 Because of its protests it is possible that Council authority is not opposable to South Africa. The uncertainty can only be finally resolved by either (i) a settlement involving all the parties or (ii) a binding judicial decision or arbitoral award. A binding judicial decision is not possible because the UN cannot be a party to contentious proceedings before the World Court and it is res judicata that individual states do not have a legal interest in the dispute as was decided by the World Court in 1966 in the case brought by Liberia and Ethiopia against South Africa. An arbitration on the matter would require mutual consent of the parties. Finally, even a decision by the Security Council under Chapter VII of the Charter could not resolve the matter legally. The Security Council may determine threats to the peace breaches of the peace and acts of aggression for the purpose of taking action. It may not determine the legal status of territory.

38 See note (10) supra.

39 Cape Times, 5th December 1985; (1986) 41 South African Shipping News and Fishing Industry Review, No. 1, p. 20.

40 See Schwarzenberger, note (46) infra, p. 209.

41 The former four reasons mentioned in note (37) supra. The latter could, at most, be the subject matter of an advisory opinion by the World Court, which would not be binding as the 1971 Opinion is not. (note (3) supra).

42 There would of course always be the question of estoppel based on Soviet acceptance of the Council since its inception. On estoppel see Schwarzenberger \& Brown, note 33 supra. pp. 70, 93, 98. Failure to object to action by the Council which is similar to that in question could also raise an estoppel, e. g. the decision that no concessions should be given in respect of non-living resources. Decree on Natural Resources, 1974. 


\section{The SWAPO Attitude}

We have seen that SWAPO has been recognized by the United Nations as the sole representative of the people of Namibia. ${ }^{43}$ Does SWAPO have to recognize the EEZ created by the Council for Namibia and what would be the legal implications of non-acceptance for the status of the EEZ in question? Here is it submitted that a preliminary distinction must be drawn between representation of the people of Namibiar and radministrative powers in respect of the territory' recognized by the United Nations. The former pertains to SWAPO while the latter is granted to the United Nations Council. The act of creating an EEZ is an administrative one and is therefore one which pertains to the Council as the administrative authority. It does not pertain to the representativer of the people through that representative may be the administrative authority at some future date in an independent Namibia. Thus prima facie a non-acceptance by SWAPO would not per se invalidate the Councils' EEZ as far as other states are concerned. It is submitted however that even at this stage the attitude of SWAPO would have some legal relevance in relation to the zone. SWAPO has been recognized by the United Nations as the sole representative of the people of Namibia. Hence good faith should require that the United Nations organs take into account the views of SWAPO on Namibian questions. ${ }^{44}$ The Council is such an organ and it is submitted that before creating an EEZ it would be obliged (1) to consult SWAPO and (2) to consider in good faith the views of the latter. Beyond this it is submitted its obligations would not extend. Hence it would not be obliged to actually follow the views of SWAPO in the last analysis. ${ }^{45}$ If however the Council did not consult SWAPO or did not take into account in good faith its views, its actions could possibly be impugned on the ground that as an international organization it had not acted in good faith. ${ }^{46}$ Such a fact would have far-reaching implications for it

43 Note (5) supra.

44 The United Nations organs must be estopped by practices they have adopted over the years in relation to nonself-governing peoples (see for example especially the Declaration by the Assembly on the Granting of Independence to Colonial Countries and Peoples 1960) from omiting of neglecting to treat with those whom they recognize as the representatives of such peoples. This must be so even if the principle of self-determination has not, as yet, finally succeeded in establishing itself as a legal principle involving specific legal rights and duties in international customary law (obviously the principle does exist as a legal one under the UN Covenants on Human Rights 1966 for parties to those Covenants).

45 SWAPO in fact did voice its objections to the creation of an EEZ at the General Assembly of the UN where it has observer status. Its objections were based on the fact that it had not been consulted. The Assembly agreed that SWAPO must be consulted before the Council takes any action on the EEZ. See (1986) 41 South African Shipping News and Fishing Industry News, No. 1, p. 20. It is submitted that if SWAPO should articulate its opposition to the substance of measures (either in advance or ex post facto) it would not be obliged to follow the action of the Council at a later stage if and laws applicable in the zone, perhaps even disregarding in the process rights acquired under the UN Regime. Quaere whether if SWAPO were consulted and approved of UN Council measures, good faith would require it to respect rights acquired under the UN Regime if and when it assumed power as a government?

46 Good faith is one of the fundamental principles applicable to international organizations. It is embodied in the Charter of the United Nations itself in Article 2 (2). Although this is formulated as an obligation for member states it is equally incumbent on the organization and its organs. See G. Schwarzenberger, International Law (1976) Vol. 111 pp. 214-216. For incidents where the good faith of international organizations has 
would in effect amount to unconstitutionality and would therefore nullify the Act of the Council. Nullity in this case would not merely be relative to SWAPO but would in effect be an absolute nullity erga omnes with all that that would imply in relation ot respect for the zone. It would mean that other states which recognize the authority of the UN Council would not be bound by its acts in casu and might therefore refuse to respect the zone created by it. ${ }^{47}$ Hence it is suggested that the Council should act with prudence in relation to SWAPO when it takes concrete steps on Namibian questions at the risk of voiding its acts.

\section{Practical Difficulties}

Even if a correct regime both from a "municipal" and an international law point of view should be created, the difficulties would only be commencing. For the Council does not possess the means to enforce its regime in the EEZ against those who refuse to observe it. It would in effect have to delegate enforcement to a state or states but this might encounter a number of difficulties. In the first place is it constitutionally capable of such delegation? The Council itself is not a primary organ of the United Nations or of its specialized agencies. It is a delegate of the General Assembly itself. Would the principle delegatus delegari non potest apply and would the Council have to refer back to the General Assembly for such power? ${ }^{48}$ In the second place would the United Nations budget be prepared to support such a patrolling activity if the General Assembly should authorize it? In the third place if the budget of the United Nations would not finance the activity, would any state or states be prepared to do it? And would the Assembly be able to agree on who those states should be? And finally what would be the response of the USSR and South Africa to such enforcement measures if they should come about? It is apparent from all the above that the practical problems of enforcing a UN EEZ could be extremely difficult. ${ }^{49}$

been impugned see dissent of Judge Sir General Fitsmaurice in the Advisory Opinion note (3) supra and the cas concerning Military and Paramilitary Activities in and Against Nicaragua. 1984. See (1985) 79 A.J.IL.. p. 439.

47 Most of the international community recognize Council authority. Moorsom, note (10) supra p. 71.

48 In Resolution 2248 (XXII) Article 11 the General Assembly decides "to entrust" to the Council "the following powers and functions to be discharged in the territory:

(a) To administer ... with the maximum possible participation of the people ...; (b) to promulgate such laws, decress and administrative regulations as are necessary for the administration ..."

The power to administer and legislate would appear to be conferred on the Council and there is no mention of a power to delegate. In the case of international organizations a presumption exists that not only are the powers expressly mentioned given to the Organization but also all power necessary to accomplish its aims unless excluded. See H. G. Schermers International Institutional Law (1972) Vol. 11, p. 488. The founding states are deemed to have intended this. It must be asked however whether this principle can be extended so as to give implied powers to the delegate of the Organisation? There is also the presumption that an international organization acts within its jurisdiction. See Schwarzenberger, note 46, supra. p. 209. Does this apply to a delegate of the Organization?

49 Moorman, note (10) supra, p. 82 concedes that as the Council has no means of enforcing its executive decisions a Council - authorised EEZ might end up as a paper decision. 


\section{A compromise provisional Solution}

In view of all the difficulties which would beset both South Africa and the UN Council in trying to preserve Namibia's marine living resources it is suggested that a compromise, interim and provisional solution should be adopted so that depletion should cease and the assets be preserved for a future Namibia in so far as it is possible to do so. This would involve co-operation which should be at an unofficial level or through the good offices of an intermediary. A number of principles should guide the formulation of a solution.

\section{Zonal Parity}

Each party could create zones as similar to each other as possible. ${ }^{50}$ The legislation of South Africa and the action taken by the United Nations Council might be regarded as separate unilateral declarations aimed at achieving a similar result. The only parties with possible rights of an administrative or jurisdictional character in relation to the territory are, in fact, South Africa and the United Nations. ${ }^{51}$ If both have similar zones (though independently of each other) this zonal geographical area, it is submitted, would be opposable to all states. The United Nations zone, if intra vires the powers of the Council, would be opposable to all states who recognize the authority of the Council. It could even be binding on the USSR by estoppel. ${ }^{52}$ Should any objection be raised on the basis that the territory does not fall subject to UN jurisdiction, the objecting state would then have to admit the continued existence of the Mandate with consequent respect for the similar zone proclaimed by South Africa. The result would be to give legitimacy to the zone thus created, its opposability to other states, including the USSR, and thus the creation on the necessary conditions for respect. Legitimate zones are generally respected in practice.

\section{Non-Prejudice to the Parties}

Neither South Africa nor the United Nations Council would recognize the rights of the other nor would any such recognition be implied from the arrangement. This non-recognition could even be made explicit in a declaration to rebut any possible implication of recognition.

\section{Respect for Licences to Fish}

Each party might grant licences to fish. The grant of these licences should be accepted in fact as the performance of routine administrative acts for the proper management of the

50 This may already have been achieved. Notes (19) and (32) supra.

51 SWAPO, as pointed out above, does not at present exercise administrative or jurisdictional rights in the territory though recognised by the UN as the representative of the people.

52 See note (42) supra. 
territory and its maritime resources by a de facto authority. ${ }^{53}$ The United Nations could regard a South African licence as one granted by a de facto occupier rather than one granted on the basis of title. ${ }^{54}$ South Africa could regard the grant of United Nations licences as being based on expediency rather than on rights. ${ }^{55}$

\section{Transparency}

Each party would have to be fully and timeously informed of the licensing acitivities of the other so that it would grant its own licences from an informed position. The problems which direct contact might pose for the parties could be resolved through the good offices of an intermediary wich could act as a clearing house.

\section{Provisional Arrangement}

It should be understood that the arrangement was to cease on Namibia's independence. Licences would have to be granted on this condition and licensees so informed. With this in mind too, licences should be granted for limited periods and then be renewed as necessary. This would have the advantage of preventing either of the parties monopolizing licensing and thus pre-empting licensing by the other.

\section{Present Exploitation}

The principle should be that appropriate licences would be given so that revenue from existing living resources should not be lost. ${ }^{56}$

\section{Appropriate Exploitation}

The policy pursued should take into account sound management and conservation principles. The overall objectives should be the rebuilding of depleted stocks and once replenished a system of exploitation based on maximum sustainable yield..$^{57}$ To achieve these aims the following would be essential.

53 Routine acts such as registration of births, deaths and marriage by a de facto authority will normally be accepted - "Acts, the effects of which can be ignored only to the detriment of the inhabitants of the territory". Advisory Opinion, Note 3 supra, paragraph 125. These could be regarded likewise.

54 An analogy could be drawn with municipal law systems, e. g. the acts of an intermeddler in an estate in the Common Law systems or the negotiorum gestor in the Civil Law systems.

55 There would be a basic problem of a practical nature to be resolved, e. g. how much of an ICSEAF quota would be allotted by the respective parties. This would be a delicate matter. Perhaps each could exercise restraint here.

56 Moorsom, note 10 supra, p. 72 regards the imposition of a tax on the income generated by of shore trawling to derive revenue for the Namibian people to be desirable objective.

57 J. R. Grindley, "The Conservation of South African Living Marine Resources", Proceedings, note (9) supra, p. 2 regards MSY without depletion of stock as the ideal for fisheries management. 


\section{(a) Recognition of Endagered Species}

The anchovy and the pilchard should be recognized as such and the utmost caution exercised in their management. ${ }^{58}$

(b) Availability of Sound Scientific Data on Stocks

This would serve as a basis for informed decisionmaking. ${ }^{59}$

(c) Due Weight to Scientific Evidence

More weight should be given to the available data than has been the case in the past. ${ }^{60}$

(d) Informed Decision-making

Decision-making bodies should have some expertise in population theory and practice. ${ }^{61}$

(e) Dynamic Regulation

This would involve flexibility and the willingness to change quotas at short notice if the latest data indicated that this would be appropriate. ${ }^{62}$

(f) Conservatism

The initial quotas should be low and restraint should be exercised. ${ }^{63}$

(g) ICSEAF Prescriptions

The various provisions of ICSEAF regulations should be observed. ${ }^{64}$

\section{Trusteeship}

Fees should be charged for licences. ${ }^{65}$ After deduction of expenses the balance should be "banked" for a future Namibia. ${ }^{66}$

58 Final Report of the Scientific Committee of Enquiry into the Exploitation of Pelagic Fish Resources of South Africa and South West Africa, p. 75. There are however very recent indications that the pilchard stock may be coming back (both in South Africa and South West Africa) but anchovy continue to be scarce (1986) 41 South African Shipping News and Fishery Industry News, No.2., p. 25.

59 See Cram, note (31) supra, pp. 143, 145; Stander, note (9) supra. p. 7. The view has recently been advanced that pilchard statistics based on landed catches are not reliable and the actual stock could therefore be much greater than the statistics indicate. See (1986) 41 South African Shipping news and Fishing Industry Review, No. 2., p. 27.

60 Cram note (31) supra, pp. 145-146. The Final Report note (58) supra points out (at. p. 74) that in 1980 the Treurnicht Commission stated "that exploitation level be determined by scientific data only" and that increased quotas for pilchard and anchovy could "only be considered disappointing and unwise".

61 Final Report, note (58) supra, p. 74.

62 Stander, note (9) supra, p. 7.

63 Final Report, note (58) supra, 74.

64 See note (9) supra. It would appear however that ICSEAF actually increased the hake quotas for 1986. This has been criticised as taking future crops before they have matured. However ICSEAF reduced the 1986 quotas for club mackerel and horse mackerel and introduced a quota for snoek for the first time. See (1986) 41 South African Shipping News and Fishing Industry Review. No. 1., p. 20.

65 See note (56) supra.

66 It is interesting to note that in 1980 South Africa proposed that catch levies be imposed on ICSEAF members to be paid to the Windhoek Administration or to an ICSEAF trust fund for Namibia. ICSEAF did not adopt a proposal. In 1982 however South Africa paid a first contribution to ICSEAF in trust. See Cram, note (10) supra, p. 72. 


\section{Consultation}

On question arising out of the arrangement SWAPO should be informally consulted, at least by the UN Council, since SWAPO is recognized as the representative of the Namibian people.

\section{Universality}

The arrangement should apply off the entire coast of the territory - including those parts which may later be the subject matter of delimitation disputes. ${ }^{67}$ It should not however prejudice such claims in any way.

\section{Informality}

The greatest degree of informality should be preserved. Formality would probably destroy any chance of success that the arrangement might have because the parties might be tempted to bolster their legal arguments in disputed matters by referring to formale legal arrangements. The arrangement should be clearly seen to create to international obligations for the parties. It should be a "comity" arrangement.

\section{Unilateral}

There should not even be an agreement - let alone a treaty. It should be an understood arrangement. Each party would implement it in fact and could make a declaration withouth prejudice to that effect if it wished. If declarations were made they could be harmonized both as to time and content through the good offices of an intermediary. An arrangement made on the basis of the above principles would preserve the positions of the three entities presently involved in the territory, South Africa, the United Nations and SWAPO. ${ }^{68}$ As far as SWAPO is concerned, its concerns would be reflected in the fact that the arrangement would be provisional, that an appropriate exploitation was being presently arranged, that the net proceeds of this were being reserved and that consultation could take place. It is clear that the concerns of South Africa and the United Nations would be overlooked either. A modus vivendi, perhaps somewhat uncomfortable, would have been achieved amongst these strange bedfellows constituting a kind of international ménage à trois!

67 See notes (21), (22), (23), supra.

68 These are the only entities which may have an international status by virtue of recognition or otherwise. Other entities are therefore not considered though they may be active economically or politically. 


\section{Conclusion}

The above solution would require a degree of tolerance and cooperation by the parties, though not necessarily direct cooperation. Any relationship involved would be unofficial and even informal. The good offices of well-disposed third parties could be used in whom both South Africa and the United Nations Council might repose their confidence. Arriving at a solution along these lines might pose difficult problems but they should not be insuperable. The price of not making the effort and of refusing to advance in fact from $a$ priori positions - even without prejudice to those positions - will be continuing depletion of Namibia's living marine resources. 
Parliament, which appears to be seen always as the true base of national interlocuteurs. Parliament's strength is sapped not only in this way; the now ill-defined formation of executive - in the public eye - becomes still more difficult to control. Abuse of power then has the tendency to multiply considerably. It is the recipe for authoritarianism.

\section{Some Thoughts on the Interim Preservation of the Namibian Fishing Heritage}

By D. J. Devine

The raison d'etre of this paper is the fact that no immediate solution of the South West Africa/Namibia political problem appears to be in sight and that the offshore living marine resources of the territory are being depleted in this period of political and legal uncertainty. The principal element which militates against the proper conservation of these resources in the absence of a 200 nautical mile fishing zone opposable to all states and recognized and respected by them. The paper does not address the problem of solving the political problems of the territory but investigates what might be done by way of interim measures to preserve the resources in question on the assumption that the overall political resolution of the territory's status may not be forthcoming for some time. Inadequacies in the existing legal mechanisms are highlighted and a plea is made for co-operation between the various political actors in an effort to preserve such valuable resources. Suggestions are made as to possible characteristics of such co-operation and ideas such as informality of arrangements, provisionality pending final solutions, transparency and consultation are examined. The hope is expressed that practical common sense will overcome a priori political positions in the search for an interim solution to avoid the continuing depletion of the resources. 